\title{
高平坦エッジ形状を実現する研磨パッド特性* （加エ前エッジ形状がエッジ形状創成過程に及ぼす影響）
}

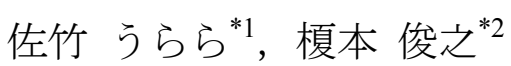

\section{Polishing Pad Specifications for Achieving High Edge Surface Flatness (Effect of Existing Edge Roll Off on Generated Edge Surface Profile)}

\author{
Urara SATAKE*1 and Toshiyuki ENOMOTO \\ ${ }^{* 1}$ Department of Mechanical Engineering, Graduate School of Engineering, Osaka University \\ 2-1 Yamada-oka, Suita, Osaka, 565-0871 Japan
}

As the substrates of semiconductor devices, silicon wafers are required to be highly flat in order to increase the integration density and the productivity of the devices. Especially edge roll off, which occurs during polishing process as the final stage of the wafer manufacturing and seriously deteriorates polished edge surface flatness, is strongly demanded to be diminished. However mechanism of generation of edge surface profile has yet to be clarified exactly, which makes it difficult to meet the demand. In this study, based on the elastic contact theory, a profile-generating model was proposed considering the effect of existing edge roll off on change in edge surface profile, concretely deterioration of flatness, improvement of flatness and convergence of profile. Based on the model, polishing pad with smaller deformation during polishing process was expected to be effective in achieving highly flat edge surface profile without edge roll off. Estimation of pad deformation and polishing experiments on silicon wafers confirmed that polishing pad with smaller deformation during polishing process achieved higher edge surface flatness.

Key Words : Polishing, Lapping, Tool, Accuracy, Polishing Pad, Edge Roll Off, Silicon Wafer

\section{1. 緒言}

半導体デバイスの高集積化にともなう配線の微細化や多層化により，基板材料であるシリコンウェー八には極 めて高い平坦性が求められている. 特に近年, 生産性向上を目的にウェー八の大口径化が進められ, それにとも ないウェー八外周部に位置するデバイスチップ数が大幅に増加したことから, ウェーハエッジ部の平坦性に関し て極めて厳しい仕様が要求されている. しかし, ウェー八製造プロセスの最終仕上げで行われる研磨加工では, 加工面エッジ部における急激な加工量の変化によりエッジ形状が大きく変化しやすく,特に エッジ部がだれるエ ッジ・ロールオフは, エッジ部の平坦性劣化の主要因として極めて重大な問題となっている. この問題を解決す るため 量産加工プロセスではリテーナリングが用いられることがあるが, 設定条件 (工作物 - リング間のクリア ランスやリングに負荷する荷重の大きさなど) の適切な選定や加工中の精確な維持が難しく 生産性低下や得られ るエッジ形状の再現性低下を引き起こすことから，リテーナリングを用いることなくエッジ・ロールオフを低減 することが強く求められている.

これまで, 加工の進行にともないエッジ・ロールオフが増大寸るメカニズムについては数多くの研究がなされ， その増大抑制に有効な研磨パッド特性や加工条件に関して様々な検討 ${ }^{(1)(3)}$ が行われてきた。 しかし, 加工の進行 にともなうエッジ形状の変化はエッジ・ロールオフの増大のみではなく, 大きくだれた面を加工する場合はエッ ジ・ロールオフの減少 すなわちエッジ形状の平坦化が起こり, またいずれにおいてもある形状へと収束すること

* 原稿受付 2012 年 6 月 26 日

*1 学生員, 大阪大学大学院工学研究科（干565-0871 大阪府吹田市山田丘 2-1）

*2 正員, 大阪大学大学院工学研究科

E-mail: satake@cape.mech.eng.osaka-u.ac.jp 
が知られている ${ }^{(4)}$. 量産加工プロセスでは，エッジ・ロールオフの増大抑制とともに 大きくだれた面をより少な い加工量で平坦化することも強く望まれており，これに応えるには，エッジ・ロールオフの増大に限らず エッジ 形状創成過程全般に関するメカニズムの解明が必須である.これまでに そのようなメカニズムの解明を試みた研 究(4)はなされているが, そこでは 加工量分布の決定に大きな影響を及ぼす工作物と研磨パッドとの接触による作 用が考慮されておらず，加工面の状態が適切に扱われていない.

そこで本研究では, 加工量分布の決定要因として工作物 - 研磨パッド間に生じる静的な接触応力の分布に着目 し，エッジ形状創成過程を表現可能な新たなモデルを提案した．そしてそのモデルにもとづき，高平坦エッジ形 状の実現，すなわち エッジ・ロールオフの増大抑制 および大きくだれた面に対する平坦化に対して有効な研磨 パッド特性を検討したので報告する.

\section{2. 加エ前エッジ形状がエッジ形状創成過程に及ぼす影響}

一般に研磨加工においては, 工作物の加工前エッジ形状が比較的平坦な場合はエッジ・ロールオフの増大が, 大きくだれている場合はエッジ・ロールオフの減少が起こり，いずれにおいても加工の進行にともないエッジ形 状はある形状へと収束する，そこでまず，そのようなエッジ形状創成過程を詳細に検討するため，初期のエッジ 形状が異なる二つのタイプの工作物, 寸なわち平坦なエッジ形状をもつ工作物と大きくだれたエッジ形状をもつ 工作物に対し，図 1 に示寸片面研磨機を用いて研磨加工実験を行った，おもな加工条件を表 1 に示寸. 工作物に

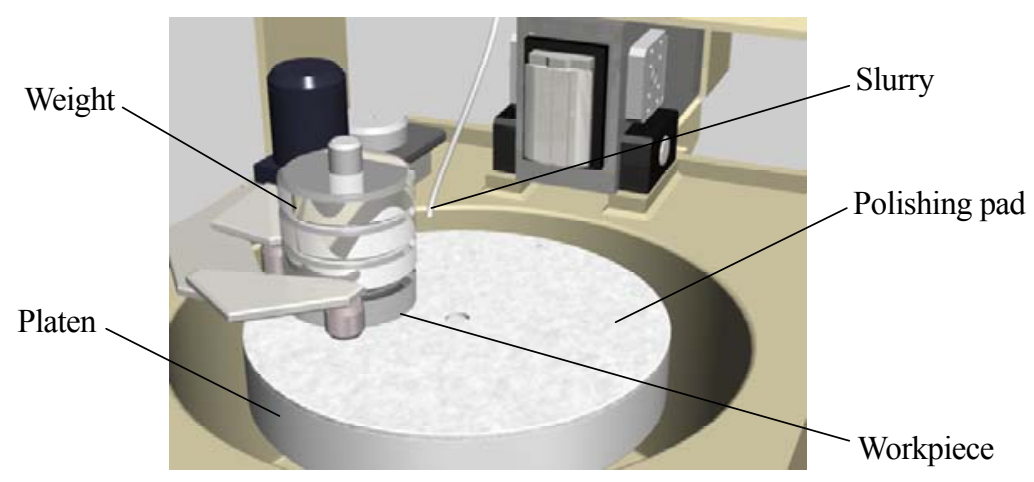

Fig.1 Schematic of single-sided polishing process

Table 1 Polishing conditions

\begin{tabular}{|c|c|}
\hline Polishing machine & $\begin{array}{l}\text { Single-sided polishing machine } \\
\text { Lapmaster SFT Corp., LP-15F }\end{array}$ \\
\hline $\begin{array}{r}\text { Workpiece } \\
\text { Rotation } \\
\end{array}$ & $\begin{array}{l}\text { Silicon wafer } 5 " \\
40 \mathrm{rpm}\end{array}$ \\
\hline $\begin{array}{c}\text { Polishing pad } \\
\text { Diameter } \\
\text { Rotation } \\
\end{array}$ & $\begin{array}{l}\text { Nonwoven pad } \\
\text { (Conditioned with } \# 55 \text { diamond disk) } \\
420 \mathrm{~mm} \\
40 \mathrm{rpm}\end{array}$ \\
\hline $\begin{array}{l}\text { Slurry } \\
\text { Supply rate } \\
\end{array}$ & $\begin{array}{l}\text { Colloidal silica }(1 \mathrm{wt} \%, 35 \mathrm{~nm}) \\
\text { Fujimi Inc., GLANZOX-1302 } \\
25 \mathrm{~mL} / \mathrm{min}\end{array}$ \\
\hline Polishing pressure & $13.5 \mathrm{kPa}$ \\
\hline
\end{tabular}




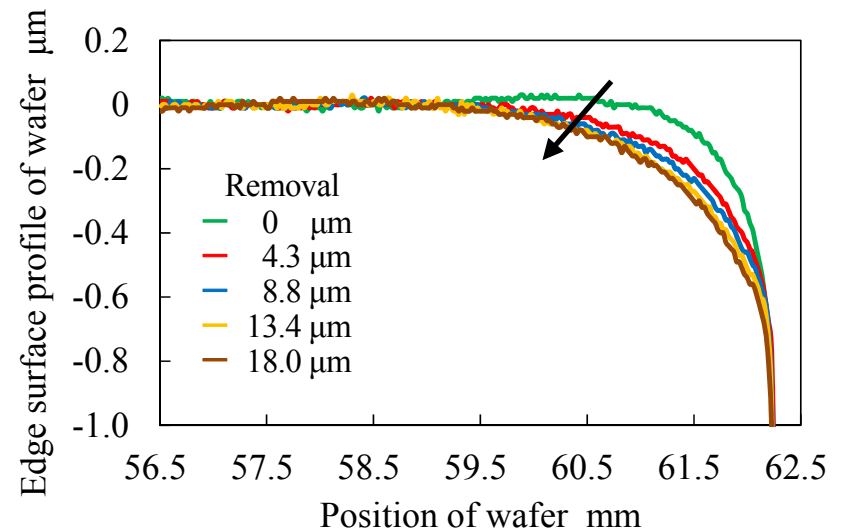

(a) Wafer with small edge roll off

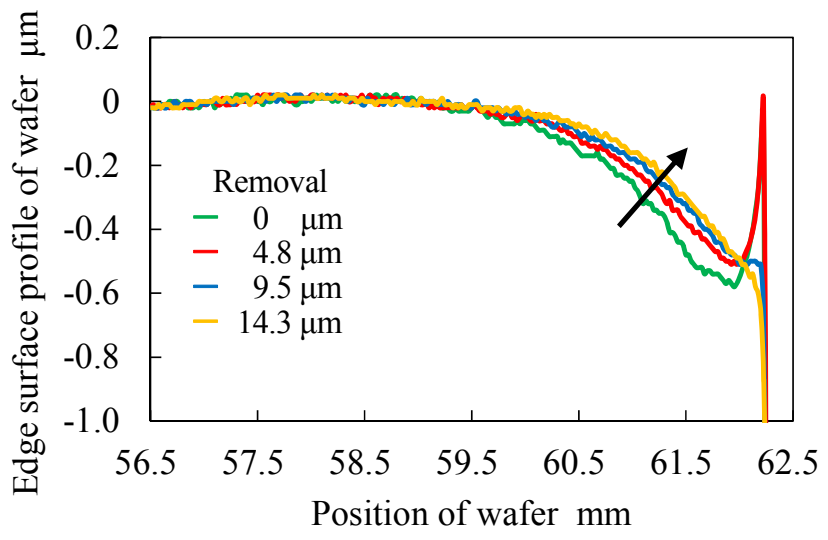

(b) Wafer with large edge roll off

Fig.2 Change in edge surface profile with accumulated removal

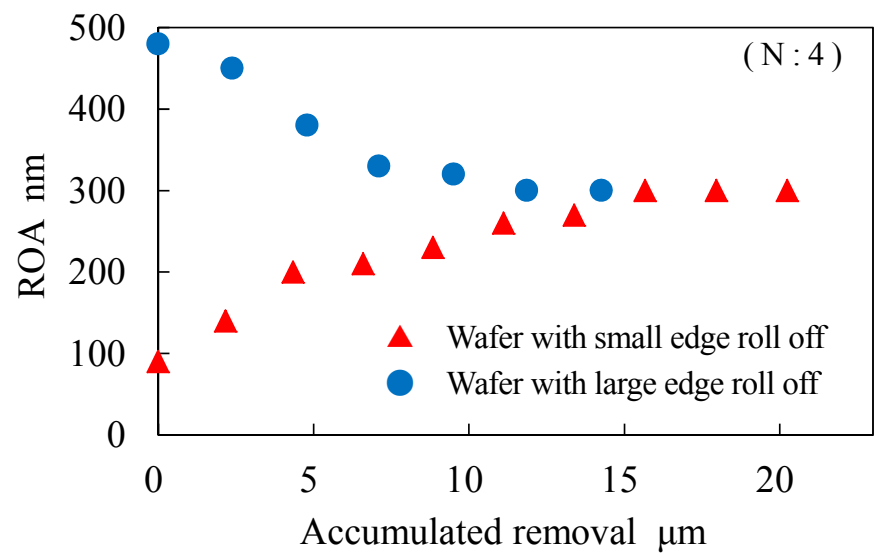

Fig.3 Change in ROA with accumulated removal

は 5 インチの単結晶シリコンウェー八を用い，ホルダを介して強制駆動で自転させた．また加工圧力はデッドウ エイトにより与えた. 研磨パッドには不織布研磨パッドを用い, 加工に供寸る前に \#55 のダイヤモンドドレッサ により表面のコンディショニングを行った. 工作物加工面の表面形状の測定は 二次元表面粗さ計 (小坂研究所製 SE3500）を用いて一枚のウェー八あたり二か所に対して行い, Roll-Off Amount (ROA) による評価も行った. ROA はエッジ部の平坦性を定量的に表わす代表的な指標の一つであり，測定した表面形状における エッジから $3 \mathrm{~mm}$ - $6 \mathrm{~mm}$ の範囲の近似直線と エッジから $1 \mathrm{~mm}$ の位置の形状との差を表わ寸. なお 加工実験は各タイプそれぞれ 二枚のウェーハに対して行った.

加工の進行にともなう各工作物のエッジ形状の変化を図 2 に, ROA の変化を図 3 に示す. 図 2 中の数值は累積 加工量を表わ寸．図からわかるとおり，初期のエッジ形状が平坦な場合はエッジ・ロールオフの増大が，大きく だれている場合は減少が見られ，いずれの場合もその増減の程度が徐々に小さくなり最終的にはある形状へと収 束した. また収束時のエッジ形状におけるエッジ・ロールオフの大きさは二つの工作物で同程度であった. なお 本実験では，大きくだれたエッジ形状をもつ工作物を加工した際，工作物最外周で加工量が大きく減少するエッ ジ上がりが生じた（図 2 (b))。これは 工作物最外周において化学的除去作用が急激に減少したためと考えられる が 詳細な原因は不明であり, 今後のさらなる検討が必要である.

ここで, 研磨加工における加工量分布は 加工面に生じる接触応力分布の影響を強く受ける. そのためこれまで に, 上述のようなエッジ形状の変化を引き起こすエッジ部近傍の加工量分布に関して, 工作物 - 研磨パッド間に 
生じる静的 / 動的な接触応力の分布に着目した検討(2),(5)-(9)がなされている. 本研究では, 研磨パッドの弾性特性 に起因して生じる工作物 - 研磨パッド間の静的な接触応力の分布に着目し, エッジ部近傍におけるその分布形状 について 弾性接触理論にもとづき詳細な検討を行った.

\section{3. 加エ前エッジ形状を考慮したエッジ形状創成モデル}

\section{$3 \cdot 1$ 加工前エッジ形状を考慮した 工作物 - 研磨パッド間の接触応力分布 \\ $3 \cdot 1 \cdot 1$ 応力集中効果と集中応力減少効果}

金属定盤に貼られた研磨パッド上に工作物が載置された状態（図 1）は，有限厚みの弾性体上に高剛性の平板 が載置された弾性接触モデルと考えることができ,このようなモデルにおいては弾性体と平板との接触面エッジ 部で応力集中が生じることが知られている(10)．このことから，研磨パッドと工作物との接触面エッジ部 すなわ ち加工面エッジ部においても応力集中が生じ, それによりエッジ・ロールオフの増大が引き起こされると考えら れる. ここでこの応力集中効果の大きさは, 弾性体の硬さにはよらず 平板の直径に対する弾性体の厚みの比が 小さいほど小さくなることが理論解析からわかっており ${ }^{(11)}$, このことから, 工作物の直径が同じ場合 研磨パッ ドの厚みが小さいほどエッジ・ロールオフの増大が抑制されると考えられる.

しかし前章の実験でも確認されたように，エッジ・ロールオフは，加工前エッジ形状が平坦な場合は増大する が 大きくだれている場合は減少する. 寸なわち 加工面エッジ部の応力は, エッジ部以外の部分の応力に比べて 常に大きくなるのではなく 加工前エッジ形状によっては小さくなる場合がある. このことから, エッジ部におけ る応力集中効果に対して 加工前エッジ形状に応じて集中応力を減少させる効果が存在すると考えられる.ここで 上述の弾性接触モデルにおいては，平板の剛性が高く全体が均一に弾性体に沈み込む場合には応力集中が生じる が, 平板の剛性が低く 平板が凹状のたわみを生じて弾性体に沈み込む場合には, その応力集中が抑制されること が知られている(10)．才なわち，弾性体が平板のたわみ形状に沿って四状に変形し 接触面エッジ部における弾性 体の変形量が中央部における変形量に対して小さくなることにより，エッジ部の集中応力を減少させる効果が現 れる. 研磨加工で用いられる工作物は剛性が極めて高くたわみをほとんど生じないが, 加工前エッジ形状にエッ ジ・ロールオフが生じている場合, 研磨パッドはそのだれた形状に沿って変形するため 加工面エッジ部における 研磨パッドの変形量 $\left(\mathrm{w}^{*}\right)$ は中央部における変形量 $(\mathrm{w})$ に対して小さくなる（図 4$)$ ）そのためこの場合も，変 形量が加工面全域で均一となる すなわち加工前エッジ形状が平坦な場合に生じるエッジ部の集中応力を減少さ せる効果が現れ，その効果は，生じているエッジ・ロールオフが大きいほど すなわち $\mathrm{w} * \mathrm{w}$ の值が小さいほど大 きくなると考えられる.

この集中応力減少効果を詳細に確認寸るため，完全に平坦なエッジ形状をもつ工作物（ROA：0 nm）およびエ ッジ・ロールオフが生じている工作物 (ROA : $60 \mathrm{~nm}, 250 \mathrm{~nm}, 1040 \mathrm{~nm}$ ) に対し, 研磨加工の構造解析 (MSC Software Corp.製 汎用非線形解析コード Marc 2011 を使用）を行った。ここでは 研磨パッド表面にあるスラリーの影響は 考慮せず，また加工要素はすべて弾性体とした．図 5 に解析に用いた二次元円筒座標系モデル（接触面近傍のメ ッシュサイズ $6.25 \mu \mathrm{m}$ ）を, 表 2 に各要素の寸法・物性值および研磨圧力を示す。ここで 工作物の直径および研 磨パッドの厚みは変化させないため, 応力集中効果の大きさはどの場合も同じである. なお各要素の物性值は,

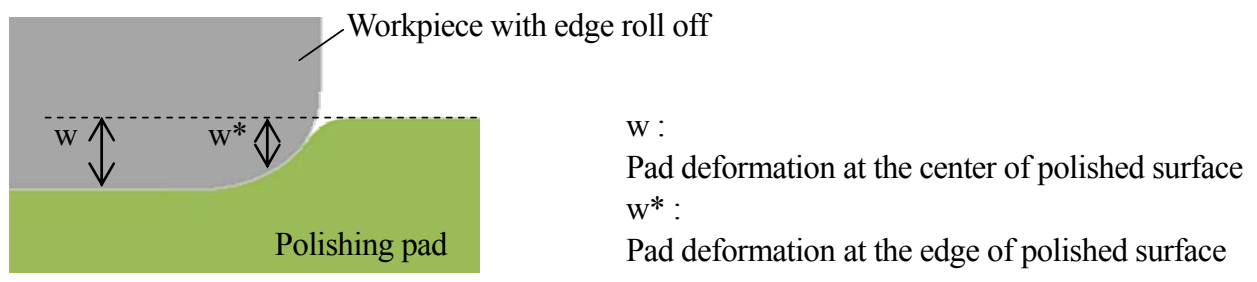

Fig.4 Deformation model of polishing pad loaded with workpiece with edge roll off 
従来研究(5),(6)における值を参考に決定した．エッジ部近傍における工作物半径方向の接触応力分布 および $\mathrm{w} * \mathrm{w}$ の值を図 6 に示す. $\mathrm{w}^{*}$ は 接触面最端部における研磨パッドの変形量とした. 同図から，エッジ・ロールオフが 生じている場合は エッジ形状が完全に平坦な場合に対してエッジ部の応力が大幅に減少し, その減少程度は, 生 じているエッジ・ロールオフが大きいほど すなわち $\mathrm{w}$ */w の值が小さいほど大きいことがわかる． 特にエッジ・ ロールオフが最も大きいモデルを用いた場合（w*/w：0.29）には，エッジ部の応力がエッジ部以外の部分の応力 を下回っており，これはエッジ・ロールオフの減少に対応する結果と言える. 以上より，加工面エッジ部では応 力集中効果により非常に大きな集中応力が生じるが，加工前エッジ形状にエッジ・ロールオフが生じている場合 は集中応力減少効果が現れ，その効果は，生じているエッジ・ロールオフが大きいほど すなわち $\mathrm{w} * \mathrm{w}$ の值が小 さいほど大きいことが確認された.

\section{$3 \cdot 1 \cdot 2$ 応力集中効果に対する研磨パッド特性の影響}

$3 \cdot 1 \cdot 1$ 項で述べたように，弾性接触モデルに対する理論解析によると，加工面エッジ部で生じる応力集中効 果を小さくし エッジ・ロールオフの増大を抑制するには，厚みが小さい研磨パッドが有効であると考えられる. そこで実際に エッジ形状の変化に対する研磨パッドの厚みの影響を確認するため, 厚みのみが異なる三種類の不 織布研磨パッド（0.25 mm 厚, $0.80 \mathrm{~mm}$ 厚，1.55 mm 厚）を用いて研磨加工実験を行った.おもな加工条件は表 1 に示したとおりである.ここでは 集中応力減少効果の影響を排除するため, 初期のエッジ形状が極めて平坦な工

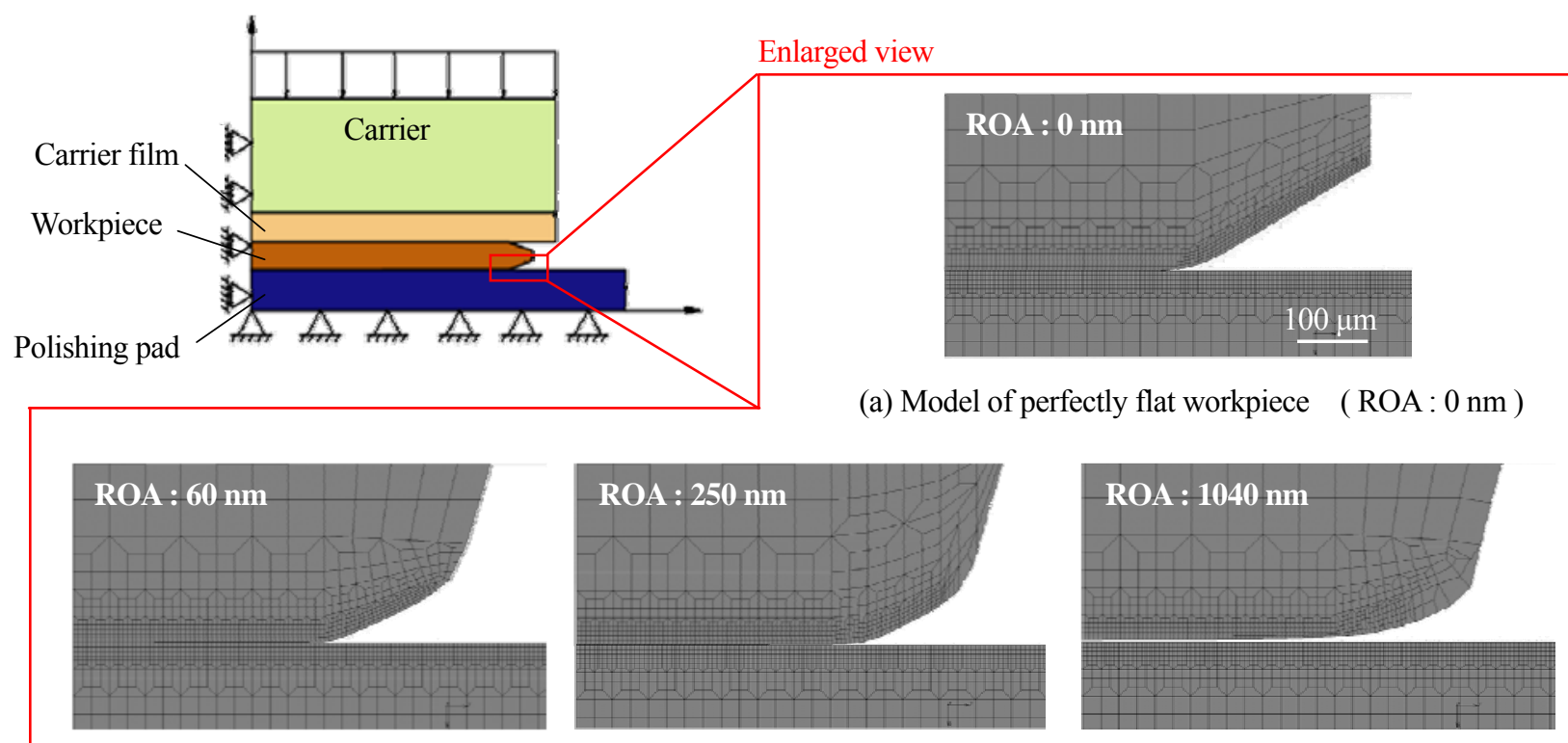

(b) Model of workpiece with edge roll off $\quad$ (ROA : $60 \mathrm{~nm}, 250 \mathrm{~nm}, 1040 \mathrm{~nm}$ )

Fig.5 Two-dimensional axisymmetric model used for structural analysis

Table 2 Geometry and material property of polishing elements and polishing pressure used for structural analysis

\begin{tabular}{|c|c|c|c|c|c|}
\hline & $\begin{array}{c}\text { Diameter } \\
\mathrm{mm}\end{array}$ & $\begin{array}{c}\text { Thickness } \\
\text { mm }\end{array}$ & $\begin{array}{c}\text { Young's modulus } \\
\mathrm{MPa}\end{array}$ & Poisson's ratio & $\begin{array}{c}\mathrm{ROA} \\
\mathrm{nm}\end{array}$ \\
\hline Carrier & 126 & 10.00 & 193000 & 0.30 & - \\
\hline Carrier film & 126 & 0.60 & 0.262 & 0.10 & - \\
\hline Workpiece & 125 & 0.70 & 193000 & 0.35 & $0,60,250,1040$ \\
\hline Polishing pad & 160 & 1.25 & 4 & 0.35 & - \\
\hline Polishing pres & \multicolumn{5}{|l|}{$13.5 \mathrm{kPa}$} \\
\hline
\end{tabular}




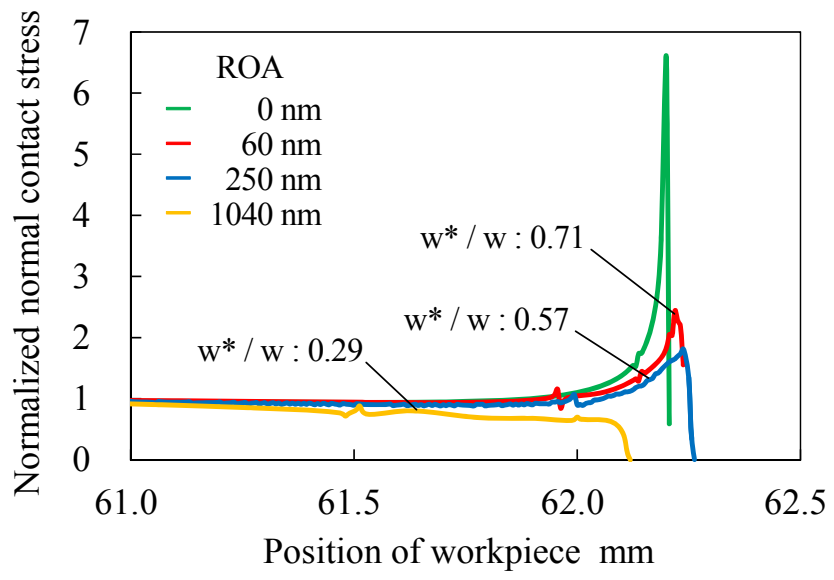

Fig.6 Effect of edge roll off on contact stress distribution

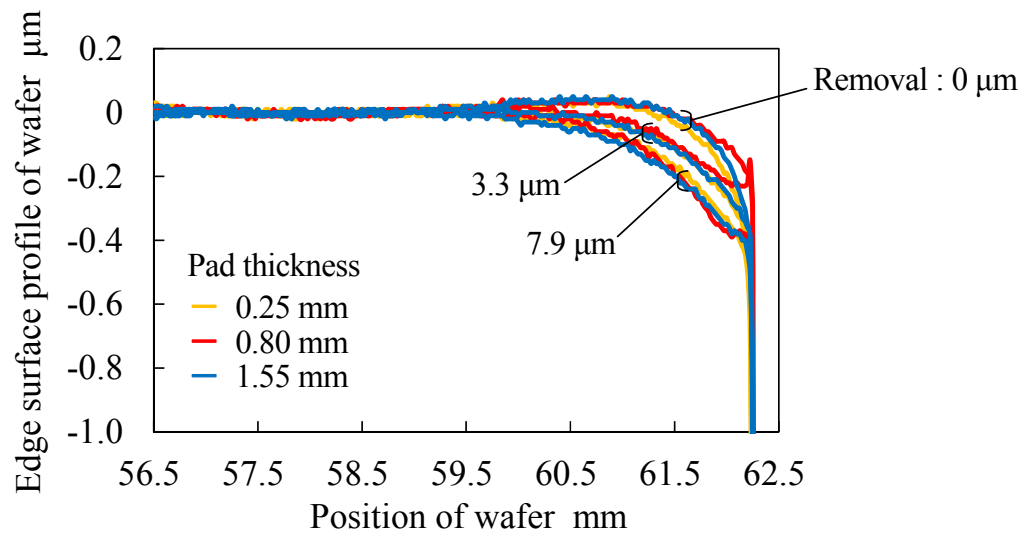

Fig.7 Effect of pad thickness on change in edge surface profile

作物を用いた. 加工の進行にともなうエッジ形状の変化を図 7 に示寸. 図中の数值は累積加工量を表わす. 同図 からわかるように エッジ形状の変化に対する研磨パッドの厚みの影響は見られず，上述の推測とは異なり 厚み が小さい研磨パッドを用いてもエッジ・ロールオフの増大は抑制されなかった．これは，今回用いた三種類の研 磨パッドの厚みの違いが極めて小さく, 厚みの違いがもたらす集中応力の大きさの違いが エッジ・ロールオフの 増大程度の違いとして確認できないほど小さかったためと考えられる. 今回の実験における工作物の直径に対す る研磨パッドの厚みの比の範囲は $0.0020 \sim 0.0124$ であり，上述した理論解析における 平板の直径に対する弾性 体の厚みの比の範囲 $0.25 \sim 1.50$ に比べ非常に狭い. 以上より, 実用的な厚みの研磨パッドを用いる場合, 応力集 中効果の大きさは 研磨パッド特性によらないと考えてよいことがわかった.

\section{$3 \cdot 1 \cdot 3$ 集中応力減少効果に対する研磨パッド特性の影響}

$3 \cdot 1 \cdot 1$ 項で行った構造解析により, 加工前エッジ形状にエッジ・ロールオフが生じている場合に現れる集中 応力減少効果は，そのエッジ・ロールオフが大きいほど すなわち $\mathrm{w}$ */w $の$ 值が小さいほど大きいことが確認され た.このことから, エッジ・ロールオフの大きさが同じ場合でも, 研磨パッドの仕様や加工条件の違いにより $\mathrm{w}^{*} / \mathrm{w}$ の值に違いが生じると 集中応力減少効果の大きさにも違いが生じることが推測される. 実際に 研磨パッドの硬 さはエッジ部の平坦性に大きな影響を及ぼすと考えられており，そこで 工作物のモデルは同一（ROA: $250 \mathrm{~nm})$ とし, 研磨パッドの弾性率 および加工条件としては研磨圧力を変化させて研磨加工の構造解析を行った. 表 3 
に 解析に用いた各要素の寸法・物性值および研磨圧力を示す． $3 \cdot 1 \cdot 1$ 項の場合と同様に，工作物の直径および 研磨パッドの厚みは変化させないため，応力集中効果の大きさはどの場合も同じである.

エッジ部近傍における工作物半径方向の接触応力分布 および $\mathrm{w} * \mathrm{w}$ の值を図 8 に示す. 同図からわかるように エッジ部の応力は $\mathrm{w} * \mathrm{w}$ の值が小さいほど小さくなり, 生じているエッジ・ロールオフの大きさが同じ場合でも, $\mathrm{w}$ */w の值が小さくなると集中応力減少効果が大きくなることを確認できた.ここで 同図の右の表に示すように, 研磨圧力が同じ場合は研磨パッドの弾性率が大きいほど, また研磨パッドの弾性率が同じ場合は研磨圧力が小さ いほど $\mathrm{w} * / \mathrm{w}$ が小さい. そこで, 研磨パッドの弾性率と研磨圧力の両者に依存寸る研磨パッドの変形量 $\mathrm{w}$ を調べ, 同表に追記した．研磨パッドの変形量 $\mathrm{w}$ が小さいほど $\mathrm{w} * / \mathrm{w}$ の值が小さく, 加工時に研磨パッドに生じる変形量 $\mathrm{w}$ が， $\mathrm{w}^{*} / \mathrm{w}$ の值 寸なわち集中応力減少効果の大きさを決める要因の一つであることがわかる．以上から，加工 前エッジ形状に生じているエッジ・ロールオフの大きさが同じ場合でも, 加工時に研磨パッドに生じる変形量が 小さくなることにより 集中応力減少効果が大きくなることがわかった.

\section{$3 \cdot 2$ 応力集中効果と集中応力減少効果にもとづくエッジ形状創成モデル}

エッジ形状の変化は エッジ部で生じる応力とエッジ部以外の部分で生じる応力との差異により引き起こされ, 前節で述べたように そのエッジ部の応力は応力集中効果と集中応力減少効果にもとづき決定される. そして, あ る一定の加工条件のもと同一の研磨パッドで加工を行う場合，応力集中効果の大きさは常に一定であるが，集中 応力減少効果の大きさは工作物のエッジ形状に応じて変化し, 生じているエッジ・ロールオフが大きい場合ほど より大きな効果が現れる.

この提案モデルにもとづき，2 章で検討を行った エッジ・ロールオフの増大・減少および形状の収束からなる

Table 3 Geometry and material property of polishing elements and polishing pressure used for structural analysis

\begin{tabular}{|c|c|c|c|c|c|}
\hline & $\begin{array}{c}\text { Diameter } \\
\mathrm{mm}\end{array}$ & $\begin{array}{c}\text { Thickness } \\
\mathrm{mm}\end{array}$ & $\begin{array}{c}\text { Young's modulus } \\
\mathrm{MPa}\end{array}$ & Poisson's ratio & $\begin{array}{c}\mathrm{ROA} \\
\mathrm{nm}\end{array}$ \\
\hline Carrier & 126 & 10.00 & 193000 & 0.30 & - \\
\hline Carrier film & 126 & 0.60 & 0.262 & 0.10 & - \\
\hline Workpiece & 125 & 0.70 & 193000 & 0.35 & 250 \\
\hline Polishing pad & 160 & 1.25 & $1,3,5$ & 0.35 & - \\
\hline
\end{tabular}

Polishing pressure : $5 \mathrm{kPa}, 13.5 \mathrm{kPa}, 25 \mathrm{kPa}$

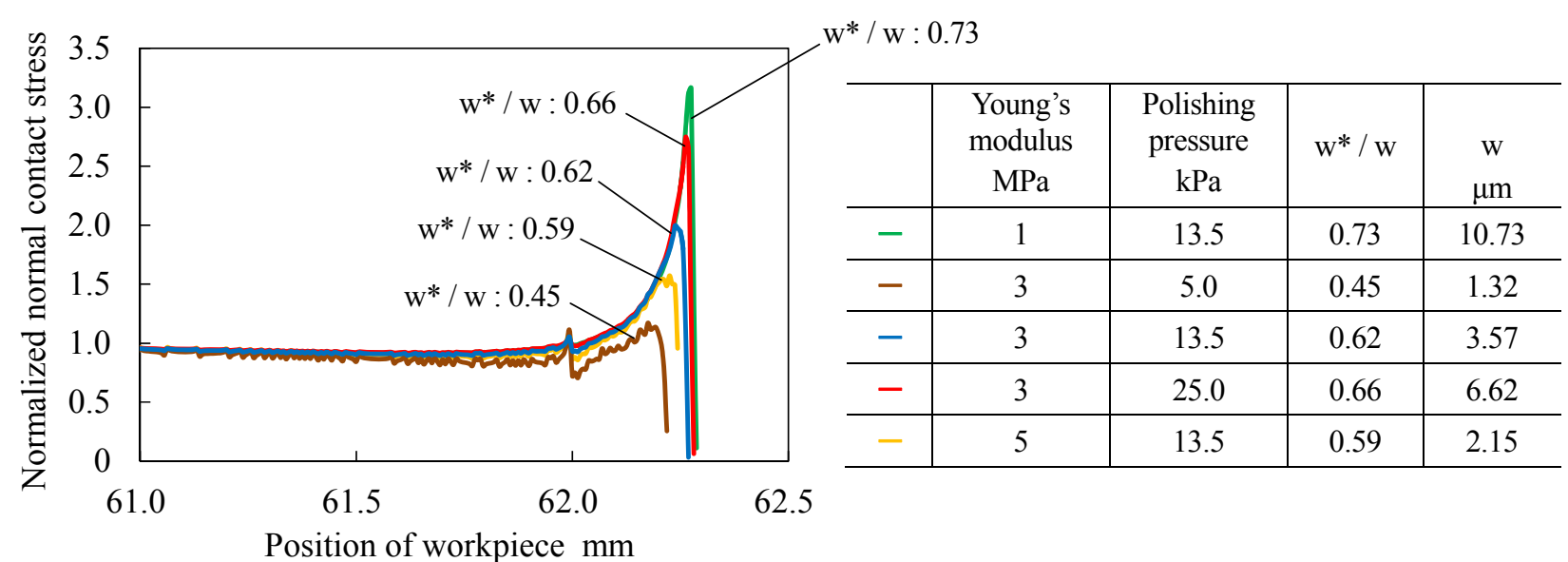

Fig. 8 Effect of pad Young's modulus and polishing pressure on contact stress distribution 
エッジ形状創成過程について考察する. 初期のエッジ形状が最終的に収束するエッジ形状に比べて平坦な場合, はじめは集中応力減少効果がほとんど現れず, エッジ部では非常に大きな応力が生じ エッジ・ロールオフが大き く増大寸る. これにより集中応力減少効果が大きくなり エッジ・ロールオフの増大程度が小さくなる. このよう にしてエッジ・ロールオフの増大にともない集中応力減少効果が徐々に大きくなり，最終的には応力集中効果を 完全に打ち消し, エッジ部の応力とエッジ部以外の部分の応力とが等しくなりエッジ形状が収束する. 一方 初期 のエッジ形状が最終的に収束するエッジ形状に比べて大きくだれている場合，集中応力滅少効果が応力集中効果 を上回り, エッジ部の応力がエッジ部以外の部分の応力よりも小さくなるため エッジ・ロールオフが減少する. これにより集中応力減少効果が小さくなり エッジ・ロールオフの減少程度が小さくなる. このようにしてエッ ジ・ロールオフの減少にともない集中応力減少効果が徐々に小さくなり，最終的には応力集中効果と等しくなり エッジ形状が収束する. 以上のように, 本提案モデルによりエッジ・ロールオフの増大・減少および形状の収束 からなるエッジ形状創成過程を表現することができた.

\section{4. 高平坦エッジ形状を実現する研磨パッド特性}

\section{$4 \cdot 1$ エッジ部の応力減少に有効な研磨パッド特性}

提案したモデルにもとづき 高平坦エッジ形状を実現する研磨パッド特性を検討する. 平坦な面を加工する際の エッジ・ロールオフの増大抑制程度 および大きくだれた面を加工する際のエッジ・ロールオフの減少程度を高め るには, いずれもエッジ部で生じる応力を減少させる必要がある.ここで エッジ部の応力は応力集中効果と集中 応力減少効果にもとづき決定され, 実用的な厚みの研磨パッドを用いる場合, 応力集中効果の大きさは研磨パッ ド特性によらない. 一方 集中応力減少効果の大きさは, 加工前エッジ形状が同じ場合は研磨パッドに生じる変形 量が小さいほど大きくなる.このことから, エッジ部の応力を減少させるには 加工時に生じる変形量が小さい研 磨パッドが有効である.

以上より，同じ加工前エッジ形状に対するエッジ・ロールオフの増大抑制程度および減少程度の決定に対して は, 厚みや硬さといった研磨パッドの仕様そのものではなくそれらの複合的な影響により決定される変形量が重 要であり, 加工時変形量が小さい研磨パッドを用いることでいずれの程度も向上寸ると考えられる. また収束す るエッジ形状は 集中応力減少効果が応力集中効果に等しくなる際のエッジ形状であるため, 収束エッジ形状の高 平坦化に対しても, 同じ加工前エッジ形状に対して現れる集中応力減少効果が大きい研磨パッドすなわち加工時 変形量が小さい研磨パッドが有効である.

\section{$4 \cdot 2$ 研磨パッドの加工時変形量がエッジ形状創成過程に及ぼす影響}

\section{$4 \cdot 2 \cdot 1$ 研磨パッドの加工時変形量評価}

前節の検討内容を確かめるため, まず 厚みや硬さが異なる三種類の不織布研磨パッド $\operatorname{Pad} \mathrm{A}, \mathrm{B}, \mathrm{C}$ に対して加 工時変形量の評価を行った。ここで, 研磨パッドの加工時変形量は極めて微小であり 実際の加工中に正確な測定 を行うことは極めて難しい，そこで 円柱圧子（直径 $10 \mathrm{~mm}$ ）による押し込み試験と構造解析を組み合わせた解 析的な評価を行った。 すなわち, 押し込み試験により得られた研磨パッドの変形特性（圧力 - 変形量関係）から

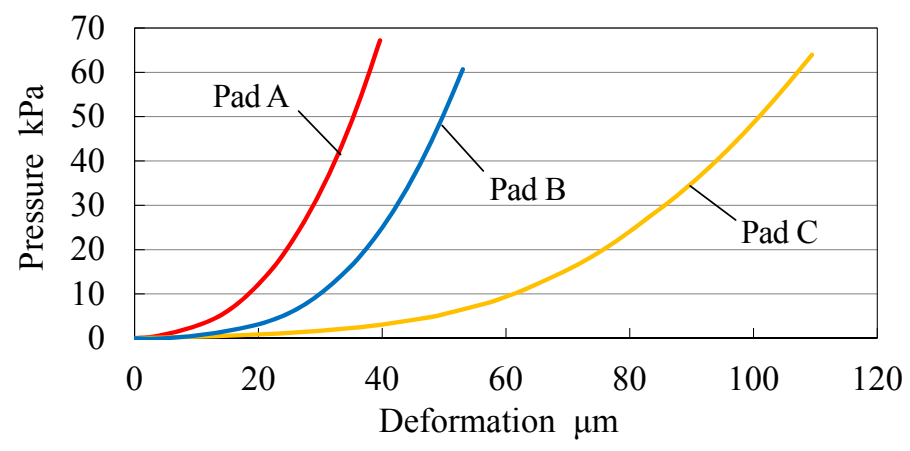

Fig. 9 Deformation characteristic of polishing pad measured by indentation test 
押し込み試験の構造解析により硬さ特性を逆解析的に同定し，それを用いて研磨加工の構造解析を行うことで加 工時変形量を算出した．押し込み試験には微小強度評価試験機（島津製作所製 マイクロオートグラフMST-I）を 用いた. 研磨加工の構造解析で用いたモデルと各要素の寸法・物性值および研磨圧力はそれぞれ図 5 と表 2 に示 したとおりである.ただし 研磨パッドの厚みは Pad A, B , C それぞれの実際の厚みとし，弾性率の代わりに上 述の方法で同定した硬さ特性を用いた.

図 9 に，押し込み試験により得られた Pad A, B , C それぞれの変形特性を示す．同図からわかるように 研磨パ ッドの変形特性は強い非線形性を示し，そのため構造解析において研磨パッドをモデル化する際は，ある弾性率 を有する線形弾性体ではなく 非線形の硬さ特性を有する非線形弾性体とした. 算出された Pad A, B , C の加工時 変形量はそれぞれ $20.4 \mu \mathrm{m}, 28.6 \mu \mathrm{m}, 59.3 \mu \mathrm{m}$ であり，これにより，同じ加工前エッジ形状に対するエッジ・ロー ルオフの増大抑制程度および減少程度は Pad A, Pad B, Pad C の順に大きく，また収束エッジ形状は Pad A, Pad B, Pad C の順に平坦になると予想された.

\section{$4 \cdot 2 \cdot 2$ 研磨パッドの加工特性評価}

前項で加工時変形量を評価した三種類の研磨パッドを用いて, 平坦なエッジ形状をもつ工作物と大きくだれた エッジ形状をもつ工作物のそれぞれに対し研磨加工実験を行った.おもな加工条件は表 1 に示したとおりである.

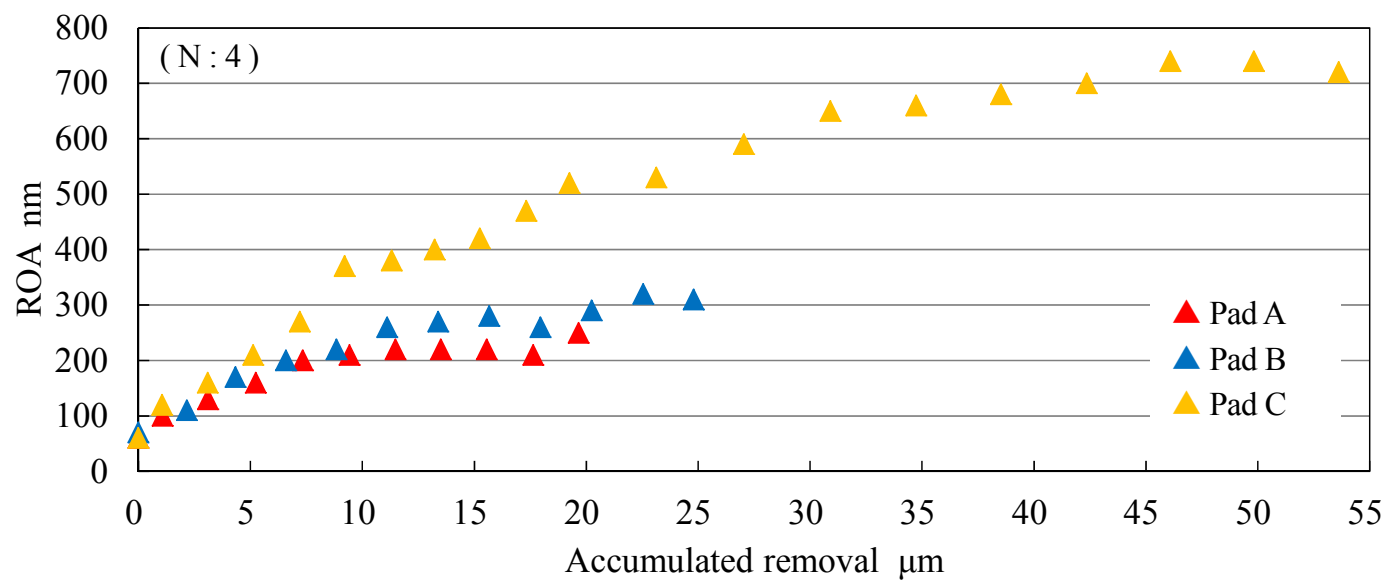

(a) Wafer with small edge roll off

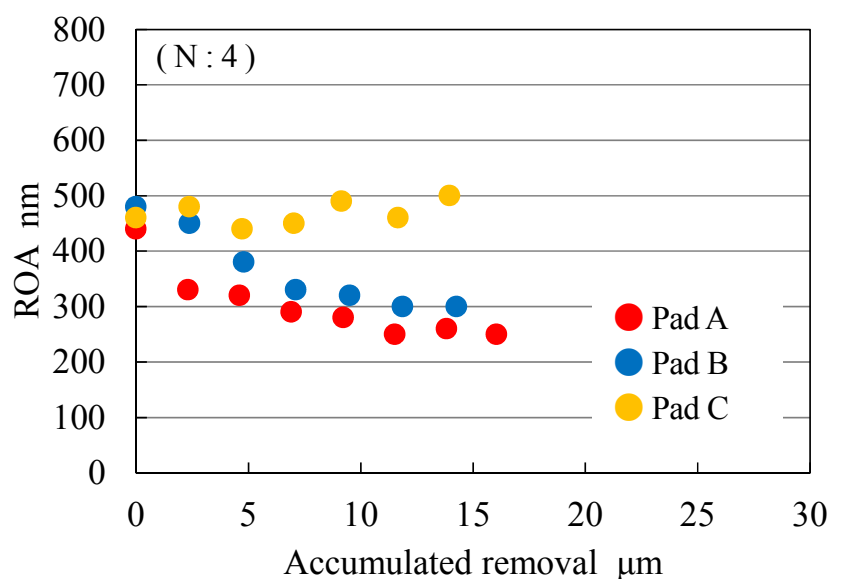

(b) Wafer with large edge roll off

Fig. 10 Change in ROA with accumulated removal 


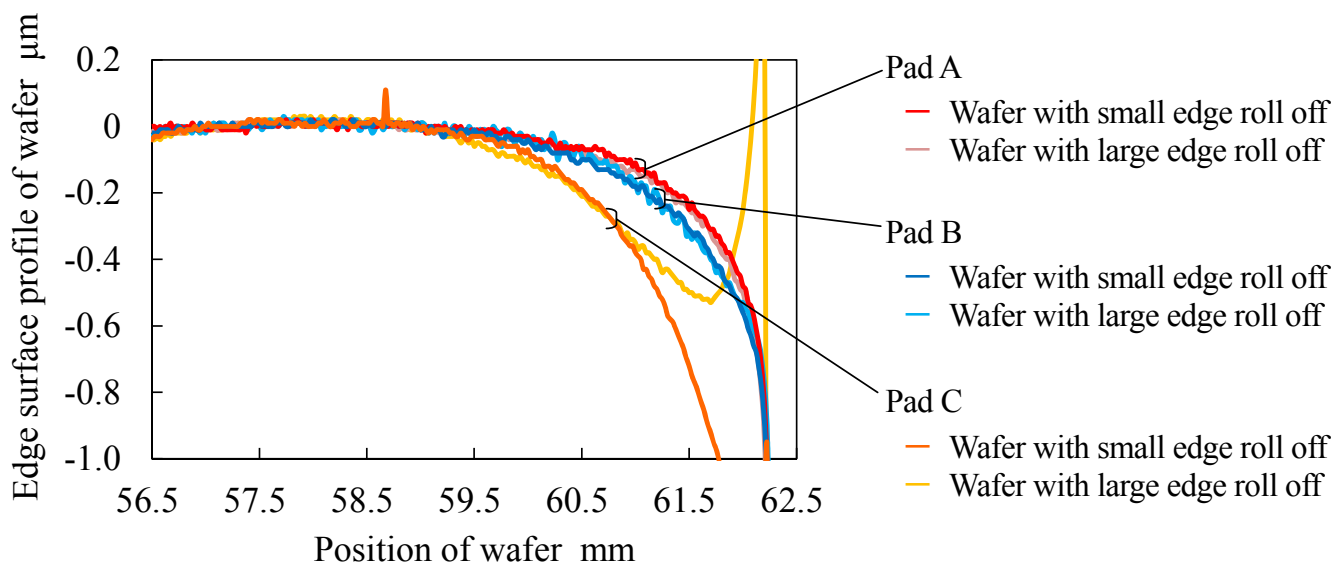

Fig. 11 Converged edge surface profile

加工の進行にともなう ROA の変化を図 10 に，各研磨パッドを用いた場合の工作物の収束エッジ形状を図 11 に 示す. 図 10 (a) から，平坦なエッジ形状をもつ工作物の加工では，加工開始後しばらくの間はエッジ・ロールオ フの増大の仕方は研磨パッドによらずほぼ同じである（累積加工量 $7 \mu \mathrm{m}$ 程度， ROA:200 $\mathrm{nm}$ 程度まで）が，エッ ジ・ロールオフが大きくなると，同程度の大きさのエッジ・ロールオフに対しては Pad A, Pad B, Pad C の順にエ ッジ・ロールオフの増大が抑制されていることがわかる.一方 大きくだれたエッジ形状をもつ工作物の加工では, 同程度の大きさのエッジ・ロールオフに対して Pad A, Pad B, Pad C の順にエッジ・ロールオフが減少した（図 10 (b)）．そしてどの研磨パッドを用いた場合も，平坦なエッジ形状をもつ工作物と大きくだれたエッジ形状をもつ 工作物はほぼ同じエッジ形状に収束し，収束エッジ形状は Pad A, Pad B, Pad C の順に平坦となった (図 11)。平 坦なエッジ形状をもつ工作物の加工において，はじめのエッジ・ロールオフの増大の仕方に研磨パッドによる違 いが生じないのは, エッジ・ロールオフが小さいために集中応力減少効果が現れず 研磨パッド特性によらない応 力集中効果の影響が支配的であるためである. 以上より, 前項で評価した加工時変形量が小さい研磨パッドほど, 同じ加工前エッジ形状に対するエッジ・ロールオフの増大抑制程度および減少程度が大きく, また収束エッジ形 状が平坦であることを明らかにできた.

\section{5. 結 言}

シリコンウェーハの研磨加工におけるウェーハエッジ形状の高平坦化を目的に, 加工前エッジ形状を考慮した エッジ形状創成モデルを提案し, そのモデルにもとづき高平坦エッジ形状を実現する研磨パッド特性を検討した. その結果, エッジ・ロールオフの増大抑制程度および減少程度の向上 そして最終的に収束するエッジ形状の高平 坦化に対し, 加工時に生じる変形量が小さい研磨パッドほど有効であることを明らかにできた.

\section{文献}

（1）益永孝幸, 須藤正昭, 小島勝義, 坂本多可雄, 川本真也, 神足勝昭, “研磨布の粘弾性回復挙動がシリコンウェー 八の外周ダレに与える影響”, 2001 年度精密工学会春季大会学術講演会講演論文集 (2001), pp. 489-490.

(2) Cai, G.Q., Lu, Y.S., Cai, R. and Zheng, H.W., “Analysis on Lapping and Polishing Pressure Distribution”, Annals of the CIRP, Vol. 47, No. 1 (1998), pp. 235-238.

(3) 戸田智之, 吉田光一, 繁田好胤, 木下正治, “研磨パッドの応力 / 変位とウェハロールオフ”, 2005 年度精密工学会 春季大会学術講演会講演論文集 (2005), pp. 853-854.

(4) 三宅貴大，榎本俊之，“研磨パッドの粘弾性特性に着目した工作物エッジ・ロールオフ生成に関する検討”, 日本機 械学会論文集 C 編, Vol. 75, No. 758 (2009), pp. 226-232.

(5) Srinivasa-Murthy, C., Wang, D., Beaudoin, S.P., Bibby, T., Holland, K. and Cale, T.S., "Stress Distribution in Chemical Mechanical Polishing", Thin Solid Films, No. 308-309 (1997), pp. 533-537. 
(6) Byrne, G.., Mullany, B. and Young, P., "The Effect of Pad Wear on the Chemical Mechanical Polishing of Silicon Wafers", Annals of the CIRP, Vol. 48, No. 1 (1999), pp. 143-146.

(7) 橋本洋平, 鈴木教和, 樋野励, 社本英二, “CMP プロセスにおける接触応力の動的有限要素法解析”, 精密工学会 誌, Vol. 77, No. 5 (2011), pp. 513-519.

(8) 河野肇, 滝田賢二, “シリコンウエー八の研磨量分布の推定”, 2002 年度精密工学会秋季大会学術講演会講演論文 集 (2002), pp. 487-488.

(9) Tichy, J., Levert, JA., Shan, L. and Danyluk, S., "Contact Mechanics and Lubrication Hydrodynamics of Chemical Mechanical Polishing”, Journal of the Electrochemical Society, Vol. 146, No. 4 (1999), pp. 1523-1528.

(10) 山口柏樹, 土質力学 (1984), pp. 341-342, 技報堂出版.

(11) 木村孟, “二層地盤の力学性状に関する解析的研究”, 土木学会論文報告集, No. 162 (1969), pp. 31-48. 